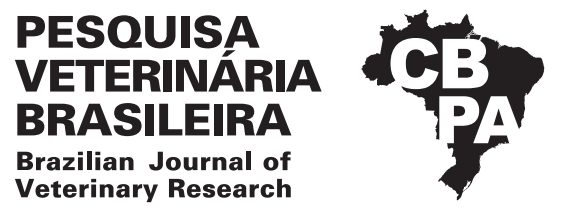

Pesq. Vet. Bras. 38(11):2146-2149, novembro 2018

ISSN 0100-736X (Print)

ISSN 1678-5150 (Online) \author{
DOI: $10.1590 / 1678-5150-P V B-5889$ \\ Original Article \\ Pequenos Animais/Small Animal Diseases
}

\title{
Epidemiological and clinical aspects of ophidian bothropic accidents in $\operatorname{dog} \mathbf{s}^{1}$
}

\author{
Laís G. Silva ${ }^{2}$, Welden Panziera ${ }^{3}$, Carlos A.S. Lessa ${ }^{4}$ and David Driemeier ${ }^{3 *}$
}

\begin{abstract}
Silva L.G., Panziera W., Lessa C.A.S. \& Driemeier D. 2018. Epidemiological and clinical aspects of ophidian bothropic accidents in dogs. Pesquisa Veterinária Brasileira 38(11):2146-2149. Setor de Patologia Veterinária, Faculdade de Veterinária, Universidade Federal do Rio Grande do Sul, Av. Bento Gonçalves 9090, prédio 42505, Porto Alegre, RS 91540-000, Brazil. E-mail: davetpat@ufrgs.br

Snakebites are included in the group of emergencies for domestic animals, and these consultations demand technical knowledge as well as careful clinical evaluation of patients. Because of the importance of this theme and the higher prevalence of snakebites caused by snakes of the genus Bothrops in Rio Grande do Sul state, Brazil, this study aimed to address the epidemiological and clinical aspects of these accidents in dogs in the state, in addition to establishing their incidence. Clinical records of dogs, with a diagnosis of ophidian bothropic accident, assisted at the Toxicological Information Center of Rio Grande do Sul (CIT-RS) were revised from 2014 to 2016. These data were collected at the Toxicological Information Center, Statistics and Evaluation Center, State Secretary of Health. Data on the incidence of accidents and epidemiological and clinical information were obtained for each case. A total of 53 records were revised. In the records that included animal sex $(n=49), 53 \%$ were female and $46.9 \%$ were male. As for animal age $(n=47)$, the dogs ranged from one to 14 years, and most of them (46.9\%) were in the 1-4-year age group. Over half of the cases occurred in the rural area (60.7\%), and the head and neck were the main venom inoculation sites $(76.3 \%)$. Diseases were characterized by clinical courses varying from hyperacute $(<30 \mathrm{~min}$ to $6 \mathrm{~h})$, acute (6-24h), to subacute (4-5 days). Severe accidents accounted for $40 \%$ of the cases, with edema as the most frequent clinical sign (88.7\%) followed by hemorrhagic manifestations $(41.5 \%)$. Associations of epidemiological and clinical aspects coupled with history of exposure are important characteristics to assist with suspicion and definitive diagnosis of bothropic accidents in dogs.
\end{abstract}

INDEX TERMS: Canine diseases, ophidian accidents, Bothrops spp., Rio Grande do Sul, toxicoses.

RESUMO.- [Aspectos epidemiológicos e clínicos dos acidentes ofídicos botrópicos em cães.] Os acidentes ofídicos se enquadram no grupo de emergências para animais domésticos e esses atendimentos demandam conhecimento

\footnotetext{
${ }^{1}$ Received on April 4, 2018.

Accepted for publication on April 18, 2018.

${ }^{2}$ Veterinary Medicine student, Faculdade de Veterinária (Favet), Universidade Federal do Rio Grande do Sul (UFRGS), Av. Bento Gonçalves 9090, Porto Alegre, RS 91540-000, Brazil. Intern, Centro de Informações Toxicológicas do Rio Grande do Sul (CIT-RS), Av. Ipiranga 5400, Jardim Botânico, Porto Alegre, RS 90610-000, Brazil.

${ }^{3}$ Setor de Patologia Veterinária, Departamento de Patologia Clínica Veterinária, Faculdade de Veterinária (Favet), Universidade Federal do Rio Grande do Sul (UFRGS), Av. Bento Gonçalves 9090, prédio 42505, Porto Alegre, RS 91540-000. *Corresponding author: davetpat@ufrgs.br

${ }^{4}$ Veterinarian, coordinator of statistical and evaluation core, Centro de Informação Toxicológica (CIT-RS), Av. Ipiranga 5400, Jardim Botânico, Porto Alegre, RS 90610-000.
}

técnico, aliado a uma criteriosa avaliação clínica do paciente. Devido à importância do tema e a maior frequência de acidentes ofídicos provocados por serpentes do gênero Bothrops no Rio Grande do Sul, esse estudo teve como objetivo abordar os aspectos epidemiológicos e clínicos desses acidentes em cães nesse estado, além de estabelecer a frequência em que ocorrem. Foram revisados os protocolos de atendimentos clínicos de cães realizados pelo Centro de Informações Toxicológicas do Rio Grande do Sul (CIT-RS) com diagnóstico de acidente ofídico botrópico, entre o período de 2014 e 2016. Esses dados fazem parte do Centro de informação Toxicológica, Secretaria da Saúde, RS, Núcleo de Estatística e Avaliação. Foram obtidos dados relacionados à frequência dos acidentes e informações referentes à epidemiologia e à clínica de cada caso. Totalizaram-se 53 registros de atendimentos. Dos protocolos que informaram o sexo $(n=49)$, $53 \%$ corresponderam a fêmeas e 46,9\%, a machos. Em relação 
à idade $(n=47)$, houve uma variação entre um e 14 anos, com maior concentração dos casos entre 1-4 anos (46,9\%). Mais da metade dos atendimentos ocorreu em zona rural $(60,7 \%)$ e a cabeça e o pescoço foram os principais locais de inoculação do veneno botrópico $(76,3 \%)$. Observou-se uma doença com um curso que variou de hiperagudo (<30 min à 6h), agudo (6-24h) a subagudo (4-5 dias). Acidentes graves representaram $40 \%$ dos casos, no qual edema foi o sinal clínico mais frequente $(88,7 \%)$, seguido por manifestações hemorrágicas $(41,5 \%)$. A associação dos aspectos epidemiológicos e clínicos, aliados ao histórico de exposição, constituem características importantes que auxiliam na suspeita e no diagnóstico definitivo do acidente botrópico em animais.

TERMOS DE INDEXAÇÃO: Doenças de caninos, acidentes ofídicos, Bothrops spp., Rio Grande do Sul, toxicoses.

\section{INTRODUCTION}

Snakebite accidents are common in humans and domestic animals in different parts of the world, and are associated with a number of factors including climate, ecological parameters, biodiversity, distribution of venomous snakes, population density, economic activities and types of dwellings. In addition, severity of the accidents varies according to the snake species involved and the amount of venom inoculated (Otero-Patiño 2009). In Brazil, accidents caused by snakes of the genus Bothrops and Crotalus are common (Amaral et al. 1985, Tokarnia \& Peixoto 2006, Nogueira 2011, Blanco \& Melo 2014, Tokarnia et al. 2014) and, more seldom, of the genus Lachesis and Micrurus (Blanco \& Melo 2014). In Rio Grande do Sul state, bothropic accidents are predominant, and are usually associated with the species Bothrops jararaca (jararaca), Bothrops neuwiedi (jararaca-pintada), and Bothrops alternatus (cruzeira) (Tokarnia \& Peixoto 2006, Dallegrave \& Sebben 2008, Herrera 2009). Owing to the proteolytic, coagulant and hemorrhagic action of bothropic venom, hemostatic disorders are the main clinical signs observed (Tokarnia \& Peixoto 2006, Otero-Patiño 2009).

Snakebites are included in the group of emergencies for domestic animals, and these consultations demand technical knowledge as well as careful clinical evaluation of patients. Because of the importance of this theme and the higher prevalence of snakebites caused by snakes of the genus Bothrops in Rio Grande do Sul state, Brazil, this study aimed to address the epidemiological and clinical aspects of these accidents in dogs in the state, in addition to establishing their incidence.

\section{MATERIALS AND METHODS}

Clinical records of dogs, with a diagnosis of ophidian bothropic accident, assisted at the Toxicological Information Center of Rio Grande do Sul (CIT-RS) were revised from 2014 to 2016. These data were collected at the Toxicological Information Center, Statistics and Evaluation Center, State Secretary of Health. Data on the incidence of accidents and epidemiological and clinical information were obtained from each case. Epidemiological aspects included sex, age, year of occurrence, and area of exposure (rural or urban). Clinical aspects were based on the history described by veterinarian in the reports. In addition, severity of the accidents, most frequent site of the bites, and existence of previous clinical care were assessed.

\section{RESULTS}

From 2014 to 2016, 53 bothropic ophidian accidents (Bothrops spp.) involving dogs were assisted at the CIT-RS. The canids involved were from cities of different regions of Rio Grande do Sul state and, in all cases, diagnosis was based on identification of snakes of the genus Bothrops or presumptively on the clinical signs presented. Of the 49 records that included animal sex, 53\% were female and $46.9 \%$ were male. Age of the animals was informed in 47 records, and ranged from $<1$ to 14 years. Age distribution of the affected dogs was as follows: 23 (46.9\%), 1 -4 years; 18 (36.7\%), 4-9 years; three $(6.3 \%)$, 10-14 years; three (6.3\%), <1 year; two (4.25\%), 15-19 years.

As for the annual distribution of the 53 consultations, $26(49 \%)$ occurred in summer, $16(30.1 \%)$ in autumn, eight (15.1\%) in spring, and three (5.6\%) in winter. Of the cases with information about the area of exposure (51/53), most of the accidents occurred in the rural area $(60.7 \%)$, followed by the urban area (39.2\%). Regarding medical assistance (50/53), $28(56 \%)$ patients were in a clinic or hospital when they were referred to the CIT-RS, 19 (38\%) received first aid in the place where they lived, two (4\%) were in a veterinary's office or outpatient clinic, and one (2\%) was under pre-hospital care on the way to veterinary assistance.

Of the records with information about location of the snakebite (38/53), 37 dogs showed only one venom inoculation site and one dog had more than one site $(2.6 \%)$. The head and neck accounted for most of the cases (76.3\%), followed by the pelvic (10.5\%) and thoracic limbs (5.2\%). Sites such as the chest, abdomen, and back represented one case each (5.2\%).

Fifty of the 53 records provided descriptions of clinical manifestations. Disease was characterized by clinical courses varying from hyperacute ( $<30 \mathrm{~min}$ to $6 \mathrm{~h})$, acute $(6-24 \mathrm{~h})$, to subacute (4-5 days). Of the 50 cases, 20 (40\%) were considered severe accidents and seven of them evolved to death. Accidents were considered severe when marked edema and hemorrhage with occasional necrosis at the bite site were observed (Fig.1 and 2). Moderate accidents (moderate edema and bleeding at the bite site) accounted for $32 \%$ of the cases, whereas mild accidents (mild edema at the bite site) totaled $28 \%$. In all cases of mild and moderate accidents, the dogs recovered completely. Edema at the bite site and

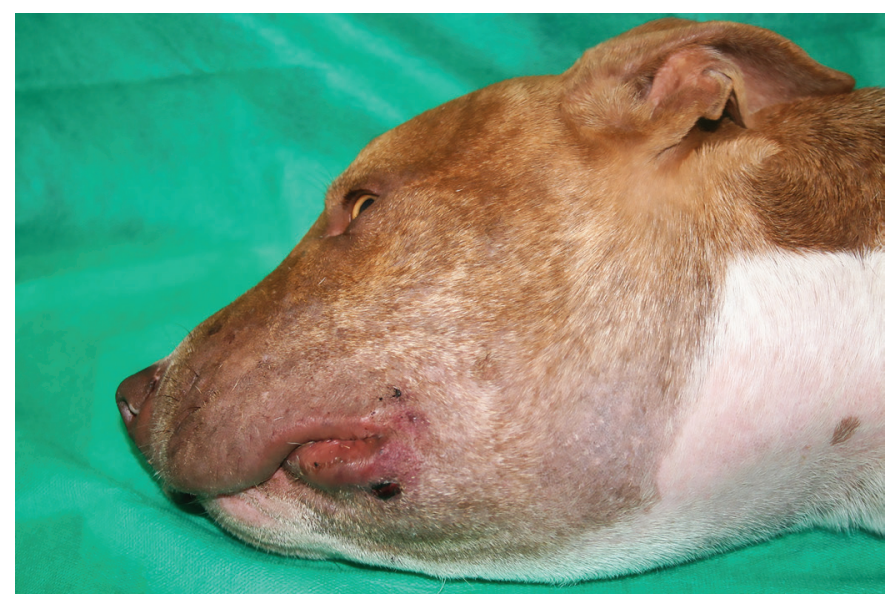

Fig.1. Ophidian bothropic accident in dog. Marked increase in submandibular and labial volume (edema) is observed. Two hemorrhagic spots corresponding to the venom inoculation site are visualized adjacent to the labial commissure. 


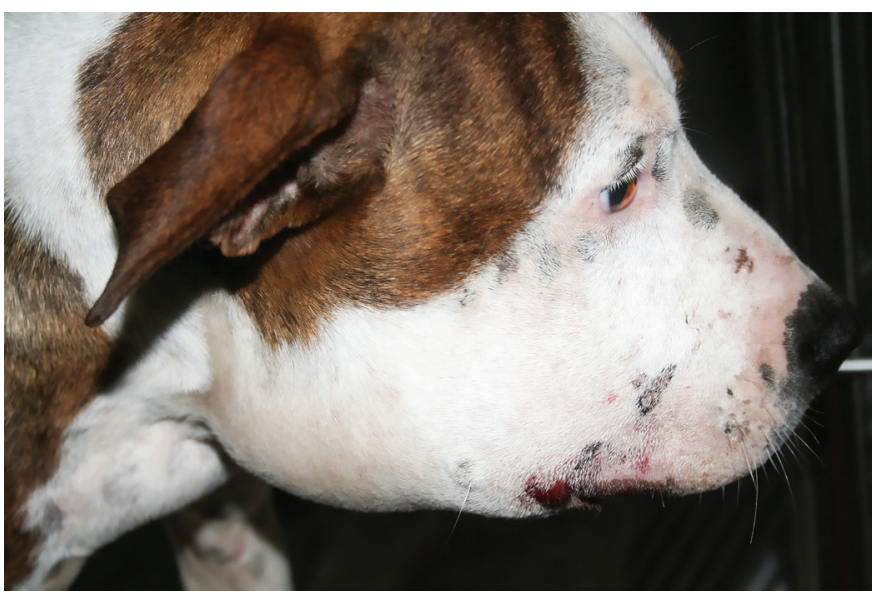

Fig.2. Ophidian bothropic accident in dog. The dog shows marked submandibular edema. The labial commissure also presents a hemorrhagic spot corresponding to venom inoculation.

adjacent tissue was the most frequently observed clinical sign (88.7\%), varying from mild to severe. Associated with edema, $22(41.5 \%)$ dogs presented hemorrhagic manifestations such as bleeding at the bite site (68.2\%), ecchymosis (18.2\%), epistaxis (4.5\%), gingival hemorrhage (4.5\%), and hyphema (4.5\%). Other clinical signs included apathy (13.2\%), pain $(11.3 \%)$, necrosis at the bite site $(3.8 \%)$, and hyperthermia (3.8\%). Hypothermia, anuria, and cardiorespiratory arrest were reported in only one case $(1.9 \%)$.

\section{DISCUSSION}

Associations of epidemiological and clinical aspects coupled with history of exposure are important characteristics to assist with suspicion and definitive diagnosis of bothropic accidents in dogs (Méndez \& Riet-Correa 2007). All species of domestic animals are affected by the venom of vipers of the genus Bothrops, but sensitivity varies between them. The domestic animal species most susceptible to this venom, in descending order, are equines, sheep, bovines, goats, canines, swine, and felines (Blanco \& Melo 2014). Despite the intermediate resistance, dogs, especially young, occupy the first positions among the domestic species involved in ophidian accidents caused by snakes of the genus Bothrops (Méndez \& Riet-Correa 2007, Nogueira 2011, Barni et al. 2012, Blanco \& Melo 2014). In this study, over half of the consultations recorded were with young canids, and this can be attributed to the inquisitive nature of this age group, associated with active behavior with habitat exploration through smell and the mouth (Méndez \& Riet-Correa 2007, Heckler et al. 2010, Nogueira 2011, Blanco \& Melo 2014). Moreover, accidents are facilitated by the aggressive behavior of snakes of this genus, even though they present the habit of staying still and camouflaged when not disturbed (Pereira 2006, Méndez \& Riet-Correa 2007).

Occurrence of ophidian accidents is also directly associated with the activity of the snakes, which increases when they are in search of food, mating, a place to spawn, and control of their body temperature. Low temperatures reduce their metabolism and, consequently, their activity (Blanco \& Melo 2014). These epidemiological aspects justify the higher incidence of accidents observed in summer in the dogs of this study and corroborate with the observation of other authors, who also reported a larger number of cases in this season (Méndez \& Riet-Correa 2007, Nogueira 2011, Blanco \& Melo 2014).

In the present study, over $60 \%$ of the ophidian bothropic accidents occurred in rural settings, which shows a relation between the natural habitat of these vipers and the presence of food (Boff 2005, Méndez \& Riet-Correa 2007, Nogueira 2011, Blanco \& Melo 2014). Serpents inhabit mainly rural areas, where they prefer humid environments such as forests, areas with crops and high vegetation, and places where rodents proliferate easily, such as barns, abandoned buildings, firewood deposits, etc. Although most of the cases in this study occurred in rural areas, it is suggested that the significant number of consultations in urban areas (approximately 40\%) is associated with sites with accumulation of food waste (garbage and grains), which attracts rodents that serve as prey for these snakes. In addition, the advancement of cities onto less populated areas and regions with ecological imbalance associated with the absence of predators promotes an increase in the ophidian population and, consequently, in the number of accident cases (Boff 2005, Méndez \& Riet-Correa 2007).

Head and neck corresponded to the anatomical regions most affected by ophidian bothropic accidents in the dogs of this study, and they are sites that may denote stronger severity to the case. These sites are frequently reported in the literature, and are associated with the habit of dogs of trying to immobilize the snakes with the mouth, either as a jest or an attack (Méndez \& Riet-Correa 2007). Unlike the dogs of the present study, lesions in cattle and horses are predominant in the limbs and abdomen (Tokarnia \& Peixoto 2006, Méndez \& Riet-Correa 2007). When the snakebite occurs in the head and neck region, there is formation of edema and hemorrhage, sometimes severe, in the spot and adjacent tissue, with occasional progression to the thoracic region. In these cases, the edema obstructs the upper airways, causing dyspnea and edema of glottis, which constitute serious secondary complications of these accidents, requiring an emergency tracheostomy (Nogueira 2011, Blanco \& Melo 2014, Cintra et al. 2014).

Severity of the clinical condition depends on the volume of inoculated venom, the size of the injured dog, the time elapsed between the accident and appropriate treatment, and the bite site (Blanco \& Melo 2014). In accordance with the literature (Azevedo-Marques et al. 2003), the accidents of the present study were classified into severe, moderate, and mild. Severe cases were more representative (40\%), with seven dogs evolving to death. In contrast, dogs with mild and moderate symptoms showed improvement. The local clinical signs emerge shortly after the bite, and are characterized by intense pain, edema, and hemorrhage (Azevedo-Marques et al. 2003, Tokarnia \& Peixoto 2006, Méndez \& Riet-Correa 2007, Nogueira 2011, Blanco \& Melo 2014, Tokarnia et al. 2014). Corroborating the literature, edema and hemorrhagic disorders were the most evident and frequent clinical manifestations observed in the dogs of this study, and they are important clinical features to assist with suspicion of bothropic poisoning. These manifestations, associated with tissue necrosis at the bite site, are due to the action of bothropic venom, which presents proteolytic or 
necrotizing, anticoagulant, and vasculotoxic (hemorrhagic) properties (Amaral et al. 1985, Barbosa et al. 2002, Méndez \& Riet-Correa 2007, Nogueira 2011, Blanco \& Melo 2014).

Hemorrhagic changes found in approximately $40 \%$ of the cases in this study are often observed in bothropic accidents. These changes may be local or systemic, and are caused by activation of the enzymes hemorrhages that cause lesions in the basement membrane of the capillaries, associated with thrombocytopenia and coagulation disorders (Tokarnia \& Peixoto 2006, Méndez \& Riet-Correa 2007, Blanco \& Melo 2014). The proteolytic action of bothropic venom is another important characteristic that is directly related to necrotic lesions clinically observed at the bite site. This change is due to activation of proteases, hyaluronidases, and phospholipases, as well as to release of inflammatory response mediators such as bradykinin, prostaglandins and leukotrienes. Activation of these enzymes and release of these mediators cause destruction in the bite site and adjacent tissue, and are accompanied by pain, blushing, local or regional edema, and tissue necrosis (Tokarnia \& Peixoto 2006, Méndez \& Riet-Correa 2007, Puzzi et al. 2008, Nogueira 2011, Blanco $\&$ Melo 2014). The deaths of the seven dogs in this study may be associated with severe systemic changes, such as hypovolemic shock, extensive bleeding, respiratory arrest, or acute renal insufficiency (Blanco \& Melo 2014).

It is important to differentiate ophidian bothropic accidents from other conditions. Among these conditions, the most important are allergic and toxic (especially poisoning by ornamental plants) diseases and accidents caused by other poisonous or venomous animals such as bees, frogs, spiders, and scorpions (Méndez \& Riet-Correa 2007, Nogueira 2011, Blanco \& Melo 2014). Accidents caused by bees or other insects can produce severe edema and represent important differentials (Nogueira 2011). In the present study, these differential diagnoses were discarded owing to absence of epidemiological evidence.

\section{CONCLUSIONS}

Dogs aged 1-4 years are the most predisposed to ophidian bothropic accidents in Rio Grande do Sul state.

The accidents occur predominantly in rural settings during summer, the head and neck are the most common sites of venom inoculation.

Clinically, ophidian bothropic accidents occur acutely and severely, with specific clinical presentation as early as the first few hours after the bite.

Edema and hemorrhages were the main clinical manifestations observed in the canine reports, followed by apathy and pain.

The association of epidemiological and clinical findings provides good subsidies for the diagnosis of ophidian bothropic accident in dogs.

Acknowledgements.- The authors are grateful to Viviane Sebben, Maria da Graça Boucinha Marques, Katia Rosane Lima de Moura da Silva, Maria Gorete Rossoni, Hudson Barreto Abella, and Raquel Luísa Breuning for their availability and collaboration in this study.

\section{REFERENCES}

Amaral C.F.S., Silva O.A., Goody P. \& Miranda D. 1985. Renal cortical necrosis following Bothrops jararaca and B. jararacussu snake bite. Toxicon 23(6):877-885. <http://dx.doi.org/10.1016/0041-0101(85)90379-4> $<$ PMid:4095703>

Azevedo-Marques M.M., Palmira C. \& Hering S.E. 2003. Acidentes por animais peçonhentos: serpentes peçonhentas. Medicina 36:480-489.

Barbosa P.S.F., Havt A., Facó P.E.G., Sousa T.M., Bezerra I.S.A.M., Fonteles M.C., Toyama M.H., Marangoni S., Novello J.C. \& Monteiro H.S.A. 2002. Renal toxicity of Bothrops moojeni snake venom and its main myotoxins. Toxicon 40(10):1427-1435. <http://dx.doi.org/10.1016/S0041-0101(02)001563> <PMid:12368112>

Barni B.S., Mottin I.B., Vidor S.B., Albuquerque P.B. \& Contesini E.A. 2012. Incidência e perfil dos animais atendidos devido a acidente ofídico no Hospital de Clínicas Veterinárias da Universidade Federal do Rio Grande do Sul entre os anos de 2005 e 2010. Acta Scient Vet. 40(Suppl.1):1-60.

Blanco B.S. \& Melo M.M. 2014. Acidente botrópico. Cad. Tec. Vet. Zootec. 75:1-77.

Boff G.J. 2005. Envenenamento por picada de serpente, gênero Bothrops: revisão. Vet. Foco 2(2):121-135.

Cintra C.A., Paulino Junior D., Dias L.G.G.G., Pereira L.F. \& Dias F.G.G. 2014. Acidentes ofídicos em animais domésticos. Encicl. Biosf. 10(18):58-61.

Dallegrave E. \& Sebben V.C. 2008. Toxicologia clínica: aspectos teóricopráticos, p.145-210. In: González H.D. \& Silva S.C. (Eds), Patologia Clínica Veterinária: texto introdutório. Universidade Federal do Rio Grande do Sul, Porto Alegre.

Heckler M.C.T., Santos F.H. \& Amorim R.M. 2010. Teste para avaliação das funções cognitivas de memória e aprendizado em cães. Neurobiologia 73(4):141-149.

Herrera M.S. 2009. Acidente com serpente do gênero Bothrops em cão: relato de caso. Revta Cient. Eletrôn. Med. Vet. 12:1-6.

Méndez M.L. \& Riet-Correa F. 2007. Envenenamento botrópico, p.31-38. In: Riet-Correa F., Schild A.L., Lemos R.A.A. \& Borges J.R. (Eds), Doenças de Ruminantes e Equídeos. Vol.2. 3ํㅡㄹ ed. Pallotti, Santa Maria. 692p.

Nogueira R.M.B. 2011. Lagartas e serpentes, p.295-315. In: Nogueira R.M.B \& Andrade S.F. (Eds), Toxicologia Veterinária. Roca, São Paulo. 323p.

Otero-Patiño R. 2009. Epidemiological, clinical and therapeutic aspects of Bothrops asper bites. Toxicon 54(7):998-1011.<http://dx.doi.org/10.1016/j. toxicon.2009.07.001><PMid:19591857>

Pereira M.T. 2006. Acidente botrópico em cães. Tese de Especialização em Clínica Médica e Cirúrgica em Pequenos Animais, Universidade Castelo Branco, Campo Grande. 46p.

Puzzi M.B., Vicarivento N.B., Xavier A., Polizer K.A., Neves M.F. \& Sacco S.R. 2008. Acidentes ofídicos. Revta Cient. Eletrôn. Med. Vet. 6(10):1-7.

Tokarnia C.H. \& Peixoto P.V. 2006. A importância dos acidentes ofídicos como causa de morte de bovinos no Brasil. Pesq. Vet. Bras. 26(2):55-68. <http:// dx.doi.org/10.1590/S0100-736X2006000200001>

Tokarnia C.H., Brito M.F., Barbosa J.D. \& Döbereiner J. 2014. Quadros clínicopatológicos do envenenamento ofídico por Crotalus durissus terrificus e Bothrops spp. em animais de produção. Pesq. Vet. Bras. 34(4):301-312. 